Yu-Min Lin • Tatsushi Kato • Seiji Satoh

Yusuke Nakamura • Yoichi Furukawa

\title{
Identification of novel polymorphisms in the AXIN1 and CDX-2 genes
}

\begin{abstract}
Axin and Cdx-2 play important roles in the tumorigenesis of human liver and colon. We have identified seven novel single-nucleotide polymorphisms (SNPs) in the $A X I N 1$ gene and three in the $C D X-2$ gene. The identification of SNPs in these cancer-associated genes establishes a basis for future investigations to detect losses of heterozygosity in tumors; these SNPs may also provide genetic background information associated with cancer risk.
\end{abstract}

Key words Single nucleotide polymorphism - Colorectal cancer $\cdot$ Hepatocellular carcinoma $\cdot$ Axin $\cdot \mathrm{Cdx}-2$

\section{Introduction}

Apart from its indispensable role in the determination of dorso-ventral structures during development, the Wnt/ wingless signaling pathway can participate in the genesis of a wide range of human cancers, including colorectal carcinoma (CRC) and hepatocellular carcinoma (HCC) (Nakamura 1997). The product of AXIN1, a gene that was first isolated from the murine Fused locus as an inhibitor of Wnt signaling (Zeng et al. 1997), was later shown to reduce $\beta$-catenin by forming a complex with $\beta$-catenin, GSK-3 $\beta$ (glycogen synthase kinase-3 $\beta$ ), and APC (adenomatous polyposis coli) (Kishida et al. 1998, Nakamura et al. 1998). By screening primary HCCs for mutations in the human homologue $(A X I N 1)$, we previously identified somatic mutations that all resulted in truncation of the predicted protein (Satoh et al. 2000). Moreover, additional experiments showed that the adenovirus-mediated gene transfer of wild-type AXIN1 inhibited growth and induced apoptosis in cultured HCC cells. These results suggested that Axin functions as a tumor suppressor.

Y.-M. Lin · T. Kato · S. Satoh · Y. Nakamura · Y. Furukawa $(\bowtie)$ Laboratory of Molecular Medicine, Human Genome Center, Institute of Medical Science, The University of Tokyo, 4-6-1

Shirokanedai, Minato-ku, Tokyo 108-8639, Japan

Tel. +81-3-5449-5372; Fax +81-3-5449-5433

e-mail: furukawa@ims.u-tokyo.ac.jp
Cdx-2, a mammalian homologue of Drosophila caudal, appears to play a crucial role in the progression of intestinal tumors. For example, Cdx-2 mutant mice tend to develop multiple intestinal polyps (Chawengsaksophak et al. 1997), and da Costa et al. (1999) observed a 4-bp deletion in the $C D X-2$ gene in DNA from a human colorectal-cancer cell line that was not deficient in either wild-type APC or $\beta$ catenin.

Recently, others have reported that polymorphisms of two important tumor suppressor genes were associated with susceptibility to the development of cancers in humans. One of the examples involved a polymorphism at codon 72 of p53; Caucasian women homozygous for arginine at codon 72 were shown to carry a seven-times-greater risk for developing human papilloma virus-associated cervical cancers than heterozygotes (Storey et al. 1998). The other example was a missense alteration of codon 1307 of $A P C$; the incidence of an $A P C$ allele that encoded a lysine residue at codon 1307 was significantly more common among a cohort of CRC patients of Ashkenazi Jewish ethnicity than among Ashkenazim who did not have colorectal cancers (Laken et al. 1997). In similar fashion, polymorphisms in other tumor suppressor genes may represent markers of cancer susceptibility in certain populations.

Here we report the identification of single-nucleotide polymorphisms (SNPs) in the $A X I N 1$ and $C D X-2$ genes in a Japanese population sample. These polymorphisms should be useful tools for detecting losses of heterozygosity $(\mathrm{LOH})$ in tumors and for examining potential associations between specific alleles and cancer risk.

\section{Materials and methods}

DNA samples

Blood samples were obtained, with informed consent, from 50 healthy Japanese individuals. Genomic DNA was prepared from each sample according to standard methods. 
Single-strand conformation polymorphism (SSCP) analysis

A 50-ng aliquot of DNA extracted from each sample was used as a template for the polymerase chain reaction (PCR). Amplifications were carried out in volumes of $25 \mu \mathrm{l}$ containing $67 \mu \mathrm{M}$ Tris $(\mathrm{pH} 8.8), 17 \mu \mathrm{M} \mathrm{NH} \mathrm{S}_{4} \mathrm{SO}_{4}, 10 \mu \mathrm{M} 2$ mercaptoethanol, $150 \mu \mathrm{M}$ dNTPs, $25 \mathrm{pmol}$ of each primer, $2 \mathrm{mM} \mathrm{MgCl}_{2}, 10 \%$ dimethyl sulfoxide (DMSO), and $1.25 \mathrm{U}$

Table 1. Primer sequences for amplifying the coding region of the $C D X$-2 gene

\begin{tabular}{|c|c|c|}
\hline $\begin{array}{l}\text { Name of } \\
\text { primer }\end{array}$ & Nucleotide sequences & $\begin{array}{l}\text { Product } \\
\text { size (bp) }\end{array}$ \\
\hline Exon1-1F & 5'-AGCCTTCAACGTCGGTCCC-3' & 233 \\
\hline Exon1-1R & 5'-GAACTTGGACAGCGCGCAG-3' & \\
\hline Exon1-2F & 5'-GACTACGGCGGTTACCACG-3' & 212 \\
\hline Exon1-2R & 5'-CAGCCATGGGCTACAGCAG-3' & \\
\hline Exon1-3F & 5'-CTCACGCGCTCAACGGTGG-3' & 147 \\
\hline Exon1-3R & 5'-GCTGCTGCAAACGCTCAACC-3' & \\
\hline Exon1-4F & 5'-CAGACTACCATCCGCACCAC-3' & 232 \\
\hline Exon1-4R & 5'-GCAGAGGCTGCGCCCCTT-3' & \\
\hline Exon $2 F$ & 5'-СТСАСТТСТССТТССТССАС-3' & 191 \\
\hline Exon2R & 5'-GACCGCCTAGCTCCCTCC-3' & \\
\hline Exon3-1F & 5'-СТТTТСТССАССТТТССАТТTC-3' & 226 \\
\hline Exon3-1R & 5'-CCTCAGTGTCTGGCTCTGTC-3' & \\
\hline Exon3-2F & 5'-CAGGTCCTCTGAGAAGTGTC-3' & 168 \\
\hline Exon3-2R & 5'-CAGAGCAATTCCAGGCTGAG-3' & \\
\hline
\end{tabular}

Taq polymerase. We used seven sets of primers for $C D X-2$ (Table 1) and 23 sets of primers to screen the entire coding region of $A X I N 1$. Reaction conditions for all primer sets were $5 \mathrm{~min}$ at $94^{\circ} \mathrm{C}$ for initial denaturing, followed by 30 cycles of $94^{\circ} \mathrm{C}$ for $30 \mathrm{~s}, 60^{\circ} \mathrm{C}$ for $30 \mathrm{~s}$, and $72^{\circ} \mathrm{C}$ for $1 \mathrm{~min}$, with final extension at $72^{\circ} \mathrm{C}$ for $5 \mathrm{~min}$, on the GeneAmp PCR system 9600 (PE Applied Biosystems, Foster City, CA, USA). For non-radioactive SSCP analysis, $0.2 \mu \mathrm{g}$ of each PCR product was diluted with formamide dye solution and electrophoresed in a $12 \%$ polyacrylamide (40:1 Acrylamide: Bisacryl-amide) gel containing $10 \%$ glycerol, at room temperature and at $4{ }^{\circ} \mathrm{C}$. Electrophoretic bands were stained with SYBR ${ }^{\mathrm{TM}}$ Green II (FMC BioProducts, Rockland, ME, USA) and detected by means of a fluorescent image analyzer (FMBIO II Multi-View; TaKaRa, Tokyo, Japan).

DNA sequencing

Aberrant PCR products detected by SSCP were purified using the QIAquick PCR Purification Kit (Qiagen, Tokyo, Japan). The DNA sequence of each aberrant sample was determined using an Applied Biosystems model 377 DNA sequencer (PE Applied Biosystems) with a Dye-Terminator Cycle Sequencing FS Ready Reaction Kit (PE Applied Biosystems).

Table 2. Allelic frequencies of SNPs of the $A X I N 1$ and the $C D X-2$ genes in 50 normal independent individuals

\begin{tabular}{|c|c|c|c|c|c|c|c|}
\hline \multirow{2}{*}{$\frac{\text { Gene }}{A X I N 1^{\mathrm{a}}}$} & \multirow[t]{2}{*}{ Codon position } & \multirow[t]{2}{*}{ Nucleotide position } & \multicolumn{3}{|c|}{ Genotypes $(n=50)$} & \multicolumn{2}{|c|}{$\begin{array}{l}\text { Allelic } \\
\text { frequencies }\end{array}$} \\
\hline & & & & & & & \\
\hline \multirow[t]{2}{*}{ Exon 1} & 31 & $93(\mathrm{~A}>\mathrm{C})$ & $\mathrm{A} / \mathrm{A}$ & $\mathrm{A} / \mathrm{C}$ & $\mathrm{C} / \mathrm{C}$ & A & $\mathrm{C}$ \\
\hline & & & 38 & 11 & 1 & 0.87 & 0.13 \\
\hline \multirow[t]{2}{*}{ Exon 1} & 111 & $333(\mathrm{C}>\mathrm{T})$ & $\mathrm{C} / \mathrm{C}$ & $\mathrm{C} / \mathrm{T}$ & $\mathrm{T} / \mathrm{T}$ & $\mathrm{C}$ & $\mathrm{T}$ \\
\hline & & & 49 & 1 & 0 & 0.99 & 0.01 \\
\hline \multirow[t]{2}{*}{ Exon 1} & 291 & $873(\mathrm{C}>\mathrm{T})$ & $\mathrm{C} / \mathrm{C}$ & $\mathrm{C} / \mathrm{T}$ & $\mathrm{T} / \mathrm{T}$ & $\mathrm{C}$ & $\mathrm{T}$ \\
\hline & & & 19 & 26 & 5 & 0.64 & 0.36 \\
\hline \multirow[t]{2}{*}{ Intron 4} & & $+17^{\mathrm{b}}(\mathrm{G}>\mathrm{A})$ & $\mathrm{G} / \mathrm{G}$ & $\mathrm{G} / \mathrm{A}$ & $\mathrm{A} / \mathrm{A}$ & G & A \\
\hline & & & 41 & 7 & 2 & 0.89 & 0.11 \\
\hline \multirow[t]{2}{*}{ Exon 5} & 465 & $1396(\mathrm{G}>\mathrm{A})$ & $\mathrm{G} / \mathrm{G}$ & $\mathrm{G} / \mathrm{A}$ & $\mathrm{A} / \mathrm{A}$ & $\mathrm{G}$ & A \\
\hline & & & 45 & 4 & 1 & 0.94 & 0.06 \\
\hline \multirow[t]{2}{*}{ Exon 5} & 526 & $1579(\mathrm{G}>\mathrm{T})$ & $\mathrm{G} / \mathrm{G}$ & $\mathrm{G} / \mathrm{T}$ & $\mathrm{T} / \mathrm{T}$ & $\mathrm{G}$ & $\mathrm{T}$ \\
\hline & & & 48 & 2 & 0 & 0.98 & 0.02 \\
\hline \multirow[t]{2}{*}{ Exon 5} & 563 & $1690(\mathrm{C}>\mathrm{T})$ & $\mathrm{C} / \mathrm{C}$ & $\mathrm{C} / \mathrm{T}$ & $\mathrm{T} / \mathrm{T}$ & $\mathrm{C}$ & $\mathrm{T}$ \\
\hline & & & 49 & 1 & 0 & 0.99 & 0.01 \\
\hline \multicolumn{8}{|l|}{$C D X-2^{\mathrm{c}}$} \\
\hline \multirow[t]{2}{*}{ Exon 1} & 61 & $543(\mathrm{G}>\mathrm{C})$ & $\mathrm{G} / \mathrm{G}$ & $\mathrm{G} / \mathrm{C}$ & $\mathrm{C} / \mathrm{C}$ & $\mathrm{G}$ & $\mathrm{C}$ \\
\hline & & & 36 & 12 & 2 & 0.82 & 0.18 \\
\hline \multirow[t]{2}{*}{ Exon 3} & 293 & $1237^{\mathrm{d}}(\mathrm{T}>\mathrm{C})$ & $\mathrm{T} / \mathrm{T}$ & $\mathrm{T} / \mathrm{C}$ & $\mathrm{C} / \mathrm{C}$ & $\mathrm{T}$ & $\mathrm{C}$ \\
\hline & & & 35 & 14 & 1 & 0.84 & 0.16 \\
\hline \multirow[t]{2}{*}{ Exon 3} & $3^{\prime}$-UTR & $+10^{\mathrm{d}, \mathrm{e}}(\mathrm{G}>\mathrm{T})$ & $\mathrm{G} / \mathrm{G}$ & $\mathrm{G} / \mathrm{T}$ & $\mathrm{T} / \mathrm{T}$ & G & $\mathrm{T}$ \\
\hline & & & 35 & 14 & 1 & 0.84 & 0.16 \\
\hline
\end{tabular}

SNP, Single nucleotide polymorphism

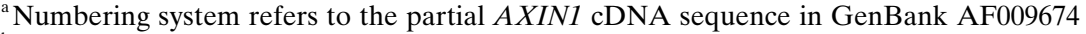

${ }^{\mathrm{b}}$ Nucleotide position is identified from the exon-intron boundary

' Numbering system refers to the $C D X-2$ cDNA sequence in GenBank NM_001265

${ }^{\mathrm{d}}$ These two nucleotides showed synchronous substitutions

${ }^{\mathrm{e}}$ Nucleotide position is identified from the stop codon 
Allelic frequencies of each SNP

The allelic frequencies of each polymorphism were determined by the band pattern of SSCP, using DNA from 50 healthy Japanese volunteers.

\section{Results and discussion}

We found a total of ten SNPs in these two tumor-suppressor genes examined. Of the seven SNPs found in the AXIN1 gene, six were located within the coding region and one in an intronic sequence. None of them would alter the aminoacid sequence of the product. Three SNPs were identified in the $C D X-2$ gene coding region; a T-to- $C$ transition at codon 293 in exon 3 would encode proline instead of serine. Table 2 indicates the nature of each SNP in both genes, and the frequency of each allele among the 50 healthy members of the Japanese population.

These SNPs will be useful not only for investigating tumors for $\mathrm{LOH}$ in the chromosomal regions where the $A X I N 1$ and $C D X-2$ genes are located (16p13.3 and 13q1213, respectively; Zeng et al. 1997; Drummond et al. 1997) but also for examining potential associations between specific alleles and cancer susceptibilities. Moreover, these SNPs can also serve as genetic markers for exploring susceptibility to a variety of other common diseases.

\section{References}

Chawengsaksophak K, James R, Hammond VE, Kontgen F, Beck F (1997) Homeosis and intestinal tumours in $\mathrm{Cdx} 2$ mutant mice. Nature 386:84-87

da Costa LT, He T-C, Yu J, Sparks AB, Morin PJ, Polyak K, Laken S, Vogelstein B, Kinzler KW (1999) CDX2 is mutated in a colorectal cancer with normal APC/ $\beta$-catenin signaling. Oncogene 18:5010 5014

Drummond F, Putt W, Fox M, Edwards YH (1997) Cloning and chromosome assignment of the human CDX2 gene. Ann Hum Genet 61:393-400

Kishida S, Yamamoto H, Ikeda S, Kishida M, Sakamoto I, Koyama S, Kikuchi A (1998) Axin, a negative regulator of the Wnt signaling pathway, directly interacts with adenomatous polyposis coli and regulates the stabilization of beta-catenin. J Biol Chem 273:1082310826

Laken SJ, Petersen GM, Gruber SB, Oddoux C, Ostrer H, Giardiello FM, Hamilton SR, Hampel H, Markowitz A, Klimstra D, Jhanwar S, Winawe S, Offit K, Luce MC, Kinzler KW, Vogelstein B (1997) Familial colorectal cancer in Ashkenazim due to a hypermutable tract in APC. Nat Genet 17:79-83

Nakamura T, Hamada F, Ishidate T, Anai K, Kawahara K, Toyoshima K, Akiyama T (1998) Axin, an inhibitor of the Wnt signaling pathway, interacts with beta-catenin, GSK-3beta and APC and reduces the beta-catenin level. Genes Cells 3:395-403

Nakamura Y (1997) Cleaning up on beta-catenin. Nat Med 3:499-500

Satoh S, Daigo Y, Furukawa Y, Kato T, Miwa N, Nishiwaki T, Kawasoe T, Ishiguro T, Fujita M, Tokino T, Sasaki Y, Imaoka S, Murata M, Shimano T, Yamaoka Y, Nakamura Y (2000) AXIN1 mutations in hepatocellular carcinomas, and growth suppression in cancer cells by virus-mediated transfer of AXIN1. Nat Genet 24:245250

Storey A, Thomas M, Kalita A, Harwood C, Gardiol D, Mantovani F, Breuer J, Leigh IM, Matlashewski G, Banks L (1998) Role of a p53 polymorphism in the development of human papillomavirusassociated cancer. Nature 393:229-234

Zeng L, Fagotto F, Zhang T, Hsu W, Vasicek TJ, Perry WL 3rd, Lee JJ, Tilghman SM, Gumbiner BM, Costantini F (1997) The mouse Fused locus encodes Axin, an inhibitor of the Wnt signaling pathway that regulates embryonic axis formation. Cell 90:181-192 